\title{
Views on psychotherapy research amongst members of the Medical Psychotherapy Faculty of the Royal College of Psychiatrists - CORRIGENDUM
}

\author{
Marcella Fok, Tennyson Lee, Jessica Yakeley
}

BJPsych Bulletin (2022) 46, 259, doi:10.1192/bjb.2021.74

\begin{abstract}
(c) The Author(s), 2021. Published by Cambridge University Press on behalf of the Royal College of Psychiatrists. This is an Open Access article, distributed under the terms of the Creative Commons Attribution licence (http://creativecommons.org/licenses/by/4.0/), which permits unrestricted re-use, distribution, and reproduction in any medium, provided the original work is properly cited.
\end{abstract}

DOI: https://doi.org/10.1192/bjb.2021.39, Published online by Cambridge University Press, 06 May 2021

Key words: Medical psychotherapy; research; psychotherapy research; academic training; survey.

In the original published article, one of the affiliations for co-author Tennyson Lee was cited incorrectly. This has now been updated in the online published article.

The authors apologise for this error.

\section{Reference}

1. Fok M, Lee T, Yakeley J. Views on psychotherapy research among members of the Medical Psychotherapy Faculty of the Royal College of Psychiatrists. BJPsych Bulletin 2021. doi: 10.1192/bjb.2021.39.

\section{CORRIGENDUM}

\section{The affective neuroscience of socioeconomic status: implications for mental health - CORRIGENDUM}

Yu Hao, Martha J. Farah

BJPsych Bulletin (2022) 46, 259, doi:10.1192/bjb.2021.99

(c) The Author(s), 2021. Published by Cambridge University Press on behalf of the Royal College of Psychiatrists. This is an Open Access article, distributed under the terms of the Creative Commons Attribution licence (http://creativecommons.org/licenses/by/4.0/), which permits unrestricted re-use, distribution, and reproduction in any medium, provided the original work is properly cited.

Keywords: Socioeconomic status; mental health; fMRI; emotion; emotion regulation.

The authors would like to correct a sentence in the above mentioned paper.

In the first paragraph in the second column on page 2, the below paragraph:

in another study, negative facial expressions elicited greater amygdala reactivity for young adults from lower-SES families, taking into account parenting quality and maternal mental health. ${ }^{17}$
Should instead read:

in another study, negative facial expressions elicited less amygdala reactivity for young adults from lower-SES families, taking into account parenting quality and maternal mental health. ${ }^{17}$

The authors apologises for this error.

\section{Reference}

1. Hao, Y, Farah M. The affective neuroscience of socioeconomic status: Implications for mental health. BJPsych Bulletin, 44, 202-207. doi:10.1192/ bjb.2020.69

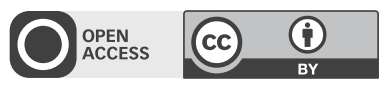

